\title{
Gambaran Tingkat Kecemasan pada Warga yang Tinggal di Daerah Rawan Banjir Khususnya Warga di Kelurahan Tikala Ares Kota Manado
}

\author{
${ }^{1}$ Chaflin T. Lamba \\ ${ }^{2}$ Herdy Munayang \\ ${ }^{2}$ Lisbeth F. J. Kandou
}

\author{
${ }^{1}$ Kandidat Skripsi Fakultas Kedokteran Universitas Sam Ratulangi Manado \\ ${ }^{2}$ Bagian Psikiatri Fakultas Kedokteran Universitas Sam Ratulangi Manado \\ Email: tommylamba@gmail.com
}

\begin{abstract}
Anxiety disorders, classified as psychiatric disorders, are usually resulting from a complex interaction of biological, psychological, and psychosocial elements. Anxiety warns the threat of injury to the body, fear, despair, the possibility of punishment, or the frustration of the need for enhanced social body, separation from loved ones, interference with the success or status of a person, and ultimately a threat to the unity or wholeness of a person. People living in areas prone to floods are assumed to suffer from anxiety of the coming floods. This study was aimed to assess the anxiety among people living in flood-prone areas by using sociodemofraphic data and questionnaire of Hamillton Anxiety Rating Scale (HARS). This was a descriptive qualitative study with a cross sectional design. There were 30 respondents that met the inclusion and exclusion criteria. The results showed that 2 (6.7\%) respondents did not have any anxiety disorder; 10 (33.3\%) people had mild anxiety disorders; $12(40 \%)$ people had moderate anxiety disorders; and $6(20.0 \%)$ people had severe anxiety disorders. Conclusion: The majority of people living in flood-prone areas suffered from anxiety and the most common type of anxiety was mild anxiety.
\end{abstract}

Keywords: anxiety, flood prone areas, HARS

\begin{abstract}
Abstrak: Gangguan kecemasan digolongkan sebagai gangguan kejiwaan, umumnya diakibatkan oleh interaksi kompleks dari elemen biologis, psikologis, dan psikososial. Kecemasan memperingatkan ancaman cedera pada tubuh, rasa takut, keputusasaan, kemungkinan hukuman, atau frustrasi dari kebutuhan sosial tubuh, perpisahan dari orang yang dicintai, gangguan pada keberhasilan atau status seseorang, dan akhirnya ancaman pada kesatuan atau keutuhan seseorang. Sebagian masyarakat yang tinggal di daerah rawan banjir mengalami kecemasan akibat takut terkena dampak bencana banjir. Penelitian ini bertujuan untuk menilai gangguan kecemasan pada warga yang berada di daerah rawan banjir dengan menggunakan data sosiodemografik dan kuesioner Hamillton Anxiety Rating Scale (HARS). Jenis penelitian ialah deskriptif-kualitatif dengan desain potong lintang. Terdapat 30 responden yang memenuhi kriteria inklusi dan eksklusi. Hasil penelitian memperlihatkan responden yang tidak mengalami gangguan kecemasan sebanyak 2 orang $(6,7 \%)$; gangguan kecemasan ringan sebanyak 10 orang $(33,3 \%)$; gangguan kecemasan sedang sebanyak 12 orang (40\%); dan gangguan kecemasan berat sebanyak 6 orang (20,0\%). Simpulan: Sebagian besar masyarakat yang tinggal di daerah rawan banjir mengalami kecemasan dan terbanyak ialah kecemasan sedang.
\end{abstract}

Kata kunci: kecemasan, daerah rawan banjir, HARS

Kesehatan jiwa adalah suatu kondisi dimana seorang individu dapat berkembang secara fisik, mental, spiritual, dan sosial sehingga individu tersebut menyadari 
kemampuan sendiri, dapat mengatasi tekanan, dapat bekerja secara produktif, dan mampu memberikan kontribusi untuk komunitasnya. ${ }^{1}$ Menurut WHO, kesehatan jiwa bukan hanya suatu keadaan tidak adanya gangguan kejiwaan melainkan mengandung berbagai karakteristik bersifat positif yang menggambarkan keselarasan dan keseimbangan jiwa yang mencerminkan kedewasaan kepribadian yang bersangkutan. $^{2}$

Masalah kesehatan dan psikologis bisa disebabkan karena kondisi lingkungan yang kurang baik. Masalah kesehatan sendiri juga dapat menyebabkan masalah psikologis yang kemudian berkaitan juga dengan masalah lingkungan. Pada para penduduk yang tinggal di daerah rawan banjir, masalah yang berkaitan dengan banjir akan terus muncul, baik masalah kesehatan, masalah lingkungan ataupun masalah psikologis. ${ }^{3}$

Gangguan kecemasan digolongkan sebagai gangguan kejiwaan, biasanya karena hasil dari interaksi kompleks dari elemen biologis, psikologis, dan psikososial. ${ }^{4}$ Jumlah pasien gangguan kecemasan mencapai $5 \%$ dari jumlah penduduk dunia. Perbandingan pasien gangguan kecemasan pada perempuan dan laki-laki ialah 2:1. Diperkirakan 2\%-4\% penduduk dunia pernah mengalami gangguan kecemasan. ${ }^{5}$

Kecemasan memperingatkan ancaman cedera pada tubuh, rasa takut, keputusasaan, kemungkinan hukuman, atau frustrasi dari kebutuhuan sosial tubuh, perpisahan dari orang yang dicintai, gangguan pada keberhasilan atau status seseorang, dan akhirnya ancaman pada kesatuan atau keutuhan seseorang. Kecemasan segera mengarahkan seseorang untuk mengambil langkah yang diperlukan untuk mencegah ancaman atau meringankan akibatnya. ${ }^{6}$

Bencana alam merupakan salah satu faktor pemicu timbulnya kecemasan, karena manusia tidak bisa memprediksikan kapan bencana alam akan muncul. Bencana ialah peristiwa atau rangkaian peristiwa yang mengancam dan mengganggu kehidupan dan penghidupan masyarakat yang disebabkan, baik oleh faktor alam dan atau faktor non-alam maupun faktor manusia sehingga mengakibatkan timbulnya korban jiwa manusia, kerusakan lingkungan, kerugian harta benda, dan dampak psikologis. ${ }^{7}$

Bencana banjir sering melanda Kota Manado khususnya pada musim hujan. Hal ini menjadikan Provinsi Sulawesi Utara sebagai salah satu daerah rawan banjir di Indonesia dan ditinjau dari luas wilayah genangan masuk dalam peringkat ke-8 dari seluruh daerah di Indonesia sehingga menjadikan Manado sebagai salah satu kota yang dinilai berisiko tinggi terhadap bahaya banjir. $^{8}$ Penelitian ini bertujuan untuk mendapatkan gambaran gangguan kecemasan pada warga yang tinggal di daerah rawan banjir di kota Manado.

\section{METODE PENELITIAN}

Jenis penelitian ini ialah deskriptifkualitatif dengan studi potong lintang untuk menilai apakah terdapat gangguan kecemasan pada warga yang berada di daerah rawan banjir dengan menggunakan data sosiodemografik dan kuesioner Hamillton Anxiety Rating Scale (HARS).

Populasi penelitian ialah warga daerah Tikala Ares lingkungan 3. Cara pemilihan sampel menggunakan cara purposive sampling. Jumlah sampel yang memenuhi kriteria inklusi dan eksklusi ialah berjumlah 30 responden.

\section{HASIL PENELITIAN}

Berdasarkan hasil penelitian yang dilakukan terhadap 30 responden didapatkan perempuan sebanyak 19 orang $(63,3 \%)$ sedangkan laki-laki sebanyak 11 orang $(36,7 \%)$. Mayoritas responden yang telibat dalam penelitian ialah pada kategori usia 56-65 tahun sebanyak 9 orang (30,0\%), beragama Kristen sebanyak 16 orang $(53,3 \%)$, tidak bekerja sebanyak 19 orang (63,3\%), dan berpendidikan akhir SMK/ SLTA yaitu 17 orang $(56,7 \%)$ (Tabel 1).

Berdasarkan hasil penelitian didapatkan bahwa responden terbanyak ialah responden yang termasuk kategori 
kecemasan sedang sebanyak 12 orang $(40,0 \%)$. Kecemasan ringan ditemukan sebanyak 10 orang $(33,3 \%)$ dan kecemasan berat sebanyak 6 orang $(20,0 \%)$. Terdapat responden yang tidak mengalami kecemasan sebanyak 2 orang $(6,7 \%)$.

Tabel 1. Distribusi frekuensi karakteristik demografik responden

\begin{tabular}{lcc}
\hline Karakteristik responden & (n) & $\mathbf{( \% )}$ \\
\hline Jenis kelamin & & \\
Laki-laki & 11 & 36,7 \\
Perempuan & 19 & 63,3 \\
Usia & & \\
Remaja akhir (17-25) & 4 & 13,3 \\
Dewasa awal (26-35) & 3 & 10,0 \\
Dewasa akhir (36-45) & 6 & 20,0 \\
Lansia awal (46-55) & 5 & 16,7 \\
Lansia akhir (56-65) & 9 & 30,0 \\
Manula (65>) & 3 & 10,0 \\
Agama & & \\
Kristen & 16 & 53,3 \\
Katolik & 5 & 16,7 \\
Islam & 9 & 30,0 \\
Pekerjaan & & \\
Bekerja & 11 & 36,7 \\
Tidak bekerja & 19 & 63,3 \\
Pendidikan terakhir & & \\
SD & 2 & 6,7 \\
SMP & 6 & 20,0 \\
SLTA/SMK & 17 & 56,7 \\
Perguruan tinggi & 5 & 16,7 \\
\hline
\end{tabular}

Tabel 2. Distribusi Responden Berdasarkan Score HARS

\begin{tabular}{ccc}
\hline Klasifikasi skor HARS & n & \% \\
\hline Tidak ada kecemasan & 2 & 6,7 \\
Kecemasan ringan & 10 & 33,3 \\
Kecemasan sedang & 12 & 40,0 \\
Kecemasan berat & 6 & 20,0 \\
Total & 30 & 100 \\
\hline
\end{tabular}

\section{BAHASAN}

Berdasarkan hasil penelitian yang dilakukan dengan cara membagikan kuesioner kepada 30 responden, ditemukan bahwa kategori jenis kelamin terbanyak ialah perempuan berjumlah 19 orang $(63,3 \%)$ yang mayoritas mengalami kecemasan ringan sebanyak 8 orang. Perempuan lebih merasa cemas akan ketidakmampuannya dibanding dengan laki-laki. Laki-laki lebih aktif, eksploratif, sedangkan perempuan lebih sensitif. Penelitian lain menunjukkan bahwa lakilaki lebih rileks dibanding perempuan. ${ }^{9}$ Berdasarkan hasil penelitian Ugwu et al. ${ }^{10}$ perempuan lebih rentan terhadap kecemasan dibandingkan laki-laki pada daerah rawan banjir karena sering dieksklusikan pada pencegahan dan persiapan bencana, termasuk dalam program intervensi darurat. Perempuan karir juga diharapkan untuk menjalankan tugas sebagai istri, ibu rumah tangga, dan merawat anak yang secara kumulatif memberikan stres psikologis yang semakin berat. Menjalankan tanggung jawab reproduktif serta merawat dan menjaga anak-anak dalam keadaan bencana, bahkan ketika mereka menangis meminta makanan ketika tak ada makanan, merupakan situasi yang sangat memicu stres dan emosional perempuan.

Responden terbanyak berdasarkan kategori usia ialah kategori masa lansia akhir (usia 56-65 tahun) yang berjumlah 9 orang $(30,0 \%)$. Mayoritas responden tersebut mengalami kecemasan ringan sebanyak 4 orang. Hal ini sejalan dengan hasil penelitian Abdullah et. al. ${ }^{11}$ yang mendapatkan kelompok usia >50 tahun sebagai kelompok yang paling rentan terhadap kecemasan di daerah rawan banjir. Usia lanjut ditandai dengan perubahan fisik dan psikologis tertentu. Demensia, osteoporosis, katarak, dan berbagai penyakit degeneratif lainnya, memperburuk fungsi lansia dalam keadaan bencana, sehingga membuat mereka lebih rentan terhadap gangguan mental dan cedera fisik saat bencana. ${ }^{12}$ Efek-efek tersebut menentukan lansia dalam melakukan penyesuaian diri secara baik atau buruk, akan tetapi ciri-ciri usia lanjut cenderung menuju dan membawa penyesuaian diri yang buruk daripada yang baik dan menuju kesengsaraan daripada kebahagiaan, itulah sebabnya mengapa usia lanjut lebih rentan dari pada usia madya. ${ }^{13}$

Responden terbanyak berdasarkan kategori agama ialah agama Kristen berjumlah 16 orang (53,3\%); mayoritas 
mengalami kecemasan ringan sebanyak 6 orang. Kategori agama di atas sejalan dengan data sensus penduduk tahun 2010 yang mendapatkan jumlah penduduk yang beragama Kristen $(62,10 \%)$, Katolik $(5,02 \%)$, Islam $(31,30 \%)$, dan sisanya beragama lain. $^{12}$

Responden terbanyak berdasarkan kategori pekerjaan ialah yang tidak bekerja berjumlah 19 orang $(63,3 \%)$. Mayoritas responden tersebut mengalami kecemasan sedang sebanyak 8 orang. Hal ini tidak sejalan dengan hasil penelitian Abdullah et al. ${ }^{11}$ yang mendapatkan pegawai negeri dan wiraswasta sebagai kelompok yang paling rentan dikalangan orang yang tinggal di daerah rawan banjir. Status pekerjaan atau ekonomi dapat memengaruhi keadaan psikologi pada individu tertentu, semakin rendah status ekonominya maka akan semakin memengaruhi keadaan psikologi individu tersebut. Orang dengan tingkat sosioekonomi yang tinggi, akan semakin mudah untuk mengakses kebutuhan dasar dan pertolongan yang dibutuhkannya dalam keadaan bencana. ${ }^{14}$

Responden terbanyak berdasarkan kategori pendidikan terakhir ialah SLTA/SMK sebanyak 17 orang $(56,7 \%)$. Mayoritas responden tersebut mengalami kecemasan ringan sebanyak 6 orang dan kecemasan sedang sebanyak 6 orang. Teori Gass dan Curiel menyatakan bahwa semakin tinggi tingkat pendidikan seseorang, semakin tinggi pula tingkat kecemasannya. Dalam keadaan pencegahan bencana, orang dengan tingkat pendidikan yang lebih tinggi cenderung lebih banyak melakukan pencegahan dan persiapan dalam menghadapi bencana, yang secara kumulatif meningkatkan stres. ${ }^{15}$

\section{SIMPULAN}

Sebagian besar masyarakat yang tinggal di daerah rawan banjir mengalami kecemasan dan terbanyak ialah kecemasan sedang.

\section{SARAN}

Penelitian ini merupakan penelitian dasar yang menggambarkan tentang tingkat kecemasan pada warga yang tinggal didaerah rawan banjir. Penelitian lanjut dengan tehnik yang lebih disempurnakan diperlukan untuk menggali faktor-faktor penyebab kecemasan.

Pemerintah perlu memerhatikan warga yang tinggal di daerah rawan banjir dengan cara pembangunan infrastruktur di daerah rawan banjir, agar warga merasa lebih aman dan nyaman.

\section{DAFTAR PUSTAKA}

1. Kementerian Hukum dan Hak Asasi Manusia Republik Indonesia. UU No.18 Tahun $2014 \quad$ Tentang Kesehatan Jiwa. [cited 2017 March 25]. Available from: URL: http://peraturan.go.id/inc/view/ 11e4b0200b77bb38b2d33132353430 30.html.

2. McGrandless A, Duffy T. Assessment and treatment of patients with anxiety. Nursing Standard. 2011;26:48-56.

3. Edesia S. Hubungan antara kualitas hidup warga DKI Jakarta yang tinggal di daerah rawan banjir [Skripsi]. Jakarta: Fakultas Psikologi Universitas Indonesia; 2008.

4. Fardhika F. Hubungan kecemasan dengan tension-type headache di Poliklinik Saraf RSUD Dr. Moewardi Surakarta [Skripsi]. Solo: Fakultas Kedokteran Universitas Muhammadiyah Surakarta; 2015.

5. Mohr C, Schneider S. Anxiety disorders. Eur Child Adolesc Psychiatry. 2013; 22:17.

6. Elvira DS, Hadisukanto G. Buku Ajar Psikiatri (1st ed). Jakarta: Badan Penerbit FKUI, 2010.

7. Amir A. Efektifitas penanggulangan bencana oleh badan nasional penanggulangan bencana. [cited 2014 Sept 29]. Available from: URL: http://repository.usu.ac.id/bitstream/1 23456789/37269/4

8. Tutik H, Susatyo Y. Hubungan kondisi kesesakan dengan kecemasan pada remaja. Proyeksi. 2012;7(2):81-7.

9. Trismiati. Perbedaan tingkat kecemasan antara laki-laki dan perempuan akseptor kontrasepsi mantap di RSUP dr. Sarijito Yogyakarta. Psyche. 2004;1(1). 
10. Ugwu LI, Ugwu DI. Gender, floods and mental health: the way forward. Int $\mathbf{J}$ Asian Social Sci. 2013;4:1030-42.

11. Abdullah S, Sipon S, Nazli NN, Puwasa NH. The relationship between stress and social support among flood victims. Procedia. 2015;192:59-64.

12. Badan Pusat Statistik. Data Sensus Agama Penduduk 2010 untuk Daerah Sulawesi Utara. 2010. [cited 2015 Jan 22]. Available from: URL: http://sp2010.bps.go.id/index.php/site $/$ tabel wid $=7100000000 \&$ tid $=321 \&$ fi $1=56 \&$ fi $2=3$.

13. Stanke C, Murray V, Amlot R, Nurse J,
Williams R. The effects of flooding on mental health: outcomes and recommendations from a review of the literature. PLOS Current Disasters (1st ed). 2012. Doi: 10. 1371/4f9f1fa9c3ae.

14. Tartowo, Wartonah. Kebutuhan Dasar Manusia dan Proses Keperawatan. Jakarta: Salemba Medika, 2003.

15. Michael $T$, Zetsche $U$, Margraf $J$. Epidemiology of anxiety disorder 2007. [cited 2015 Jan 22]. Availabel from: URL: http://www.sciencedirect. com/science/article/pii/S1476179306 700659 . 